\title{
Interdisciplinarity, and Interdisciplinarity in a Comparatist Perspective, in Contemporary Twenty-first Century British Civilisation Studies
}

L'Interdisciplinarité dans une perspective comparatiste: le cas des études en civilisation britannique contemporaine

Sam Coombes

\section{(2) OpenEdition}

\section{Journals}

Electronic version

URL: http://journals.openedition.org/rfcb/2793

DOI: $10.4000 /$ rfcb. 2793

ISSN: 2429-4373

\section{Publisher}

CRECIB - Centre de recherche et d'études en civilisation britannique

\section{Electronic reference}

Sam Coombes, «Interdisciplinarity, and Interdisciplinarity in a Comparatist Perspective, in Contemporary Twenty-first Century British Civilisation Studies », Revue Française de Civilisation Britannique [Online], XXIV-1 | 2019, Online since 22 March 2019, connection on 02 May 2019. URL http://journals.openedition.org/rfcb/2793; DOI : 10.4000/rfcb.2793

This text was automatically generated on 2 May 2019.

\section{c)}

Revue française de civilisation britannique est mis à disposition selon les termes de la licence Creative Commons Attribution - Pas d'Utilisation Commerciale - Pas de Modification 4.0 International. 


\title{
Interdisciplinarity, and
} Interdisciplinarity in a Comparatist Perspective, in Contemporary Twenty-first Century British Civilisation Studies

\author{
L'Interdisciplinarité dans une perspective comparatiste : le cas des études en \\ civilisation britannique contemporaine
}

\section{Sam Coombes}

\section{Introduction}

Interdisciplinarity has been in vogue for some years in humanities research. It would be no exaggeration to claim that the term is sometimes employed today as if it were almost a sine qua non for creative and methodologically astute research. Whilst the move in the direction of interdisciplinarity should indeed be welcomed as a valuable development in relation to the more traditional separation of disciplines which were defined and at times artificially created by the institutionalisation of knowledge in university systems, it nevertheless throws up a range of complex issues. The very fact that the traditional disciplines have often been defined and demarcated in contrasting ways in different academic systems is ample proof that the very notion of a discipline within the context of academia must be handled as a relative construct. What is known as 'continental philosophy' in the anglophone world and is as often as not taught in foreign language departments finds its natural home in philosophy departments in France for example. Conversely, civilisation britannique has no exact equivalent in English studies departments in the United Kingdom. In what follows, some of the key antecedents to interdisciplinary methodologies today in both the British and French contexts will be discussed. The ways in which the growth of a range of new critical discourses in the humanities notably since 
the 1970s has facilitated the development of interdisciplinarity more broadly conceived will be highlighted. Some possible avenues for further interdisciplinary exploration in the field of civilisation britannique will then be explored. Finally, I will make the case for further encouraging comparative studies in all areas of humanities research and will argue that the work of the later Édouard Glissant offers a valuable theoretical basis for the developing of comparatist methodologies.

2 The matter of what constitutes interdisciplinarity in the field of civilisation britannique will be of particular interest to us, and the issue cannot be addressed without taking account of the central disciplinary distinction in French anglophone studies between littérature and civilisation. It is useful at the outset to relativise this distinction which creates a disciplinary separation within English studies between research with an aesthetic and notably literary focus and all the non-aesthetic areas of the field such as sociology, politics and history that are placed in the civilisation category. It might appear that civilisation is by and large coextensive with cultural studies but it is clear that this categorization is not fully appropriate to describe the field, not least because "cultural studies" also existed as a field in its own right-even though it is a now somewhat out of favour-within British academia. 'Civilisation' can be assumed to be broader in extent than cultural studies but can it really be a catch-all term for everything that isn't literary studies? Indeed, it would be fair to state that to some extent civilisation britannique is defined as much by what it is not, namely British literary studies, as by what it is. One might also query the somewhat dichotomous nature of such a distinction. How can all aspects of a subject which are non-literary be commensurate in disciplinary terms with the study of literature, however much literary studies was considered for many decades to be a privileged point of access to a culture? We will return to this matter at a later stage in the article.

3 By way of a final introductory remark, one cannot form a clear idea of interdisciplinarity without first understanding what is meant by a discipline and it is academic institutions and traditions that have created disciplines at least in the forms we know them in today. It is from this basic fact that the need to relativise disciplinary definitions and boundaries stems. In reality, what is encompassed by littérature and civilisation taken together is globally broader than what is studied in English departments in the UK. Civilisationnistes specifically are sociologists, historians, historians of ideas, political scientists amongst other specialisms whereas they would most likely find themselves in departments corresponding to those specific areas in the UK, that is in departments such as Sociology or Politics which had nothing to do with the study of a language.

\section{New Critical Discourses and Interdisciplinarity}

4 A major feature of the modern college and university is its emphasis on the importance of interdisciplinary research (and to a lesser but real extent teaching), an emphasis often backed with substantial funding. Duke University lists seven signature interdisciplinary institutes, four interdisciplinary initiatives [...] In this respect, Duke is reasonably typical ${ }^{1}$.

This claim with respect to the U.S. academic system by and large also holds for its British counterpart where interdisciplinarity is similarly encouraged today through the selfdeclared priorities of research funding schemes and channels. Central however to the prioritising of interdisciplinary research projects has been the rise and increasing 
prominence of new critical discourses which often by their very nature cross disciplinary boundaries. These discourses first took shape as subjects for academic enquiry in anglophone universities and have in more recent years been taken up and developed also by French academic researchers. Fields such as postcolonial studies, cultural studies, queer studies and more recently trauma studies, to name a few prominent new critical discourses, all incorporate numerous subject-areas within their span: various combinations of politics, sociology, literary and film studies, just to name a few of the subject-areas which fall within their purview, can be identified in these new discourses. Insofar as civilisation britannique can by its very nature incorporate so many of these discourses it invites interdisciplinary explorations and this is surely one of its strengths. There is hence a natural propensity, as potential at least, for civilisationnistes, like those researchers who specialise in the new critical discourses, to tend towards interdisciplinarity.

\section{Cultural Studies re-visited and the centrality of interdisciplinarity}

6 I home in on the definition of civilisation and its relationship to 'Cultural Studies' partly because there is a consensus in the critical literature that Cultural Studies was one of the pioneering interdisciplinary fields in the humanities in Britain. ${ }^{2}$ The birth of Cultural Studies is associated with the creation of the Centre for Contemporary Cultural Studies (CCCS) in Birmingham that Stuart Hall directed from 1969-1978 and which emphasized sociological notions of culture. The approach it adopted was very wide-ranging. It was receptive to the theories and methods of other disciplines such as history, philosophy and politics, and Hall and his colleagues set themselves apart from the postivistic strain of sociology leading back to Auguste Comte and Emile Durkheim. Their sociological focus extended to ethnography as well as social and cultural anthropology and met with scepticism from the 'hard' social scientists who were more concerned with statistical and quantitative research methods. Being a non-disciplinary field, cultural studies has taken its lead from diverse fields and academic traditions. Stuart Hall has identified as intellectual antecedents such sources as Marx, Weber, Michel Foucault, Georg Lukács Raymond Williams, E.P. Thompson, Roland Barthes, Howard Becker, Louis Althusser, as well as feminist theorists. ${ }^{3}$ Indeed, the diversity of its range of intellectual influences has led to cultural studies sometimes being referred to as an "anti-discipline."

One area of originality of the CCCS was its members' interest in applying ethnographic methods to modern western societies, thereby thoroughly blending sociology and ethnography. This approach involved an implicit rejection of the traditional prioritising of textual criticism, involving as it did participant observation. Culture was to be studied in the broadest sense of the term being taken to include social groups, rituals, everyday practices and different sorts of media. Projects encompassed for example analysing the ways in which skinheads and punks employed ritualistic practices as part of a strategy of resistance. The focus was very contemporary moreover.

These priorities set the work of the CCCS apart from mainstream sociology. Moreover, literary studies were by and large excluded from the research work undertaken, yet another departure from the conventions and hierarchies of the traditional academic establishment. Documents of general sociological interest like contemporary magazine 
publications were given priority, not literary texts. Cultural studies hence intrinsically challenged the idea of literature as lying at the core of the humanities. It similarly, by its very nature, challenged the notion that the pursuit of knowledge in the contemporary context could be meaningfully pursued whilst working in only one discipline. It set out rather to create a space between disciplines in order to examine diverse forms of culture in relation to questions of power.

9 A centre of interest for Hall and cultural studies was the question of representation and the ways in which representation can and is harnessed by hegemonic forces. Indeed cultural studies generally tended to focus on the ideological, oppressive implications of culture, taking a critical as opposed to purely analytical view of it. Representation for Hall is intimately linked to questions of semiotics and in particular the ways in which signs are commonly employed to project certain images in the interests of portraying a certain image of a phenomenon rather than merely reflecting it. An image of a woman on the cover of a fashion magazine, for example, can never be assumed to be an innocent representation because it invariably encourages a certain response in the viewer and hence constitutes some sort of reconstruction of existing ideas about women. Underpinning the image of the woman there is a world of ideas, beliefs that must be deconstructed as well as perhaps a commercial agenda. Hence a critical approach to cultural studies views representation as an ideologically motivated act of reconstruction that serves the interests of those who control or use the media. Moreover, cultural studies tends to be interested in the operations of the mass media as the organs used by hegemonic powers in the interests of the dissemination of ideological values.

From representation via signs Hall extrapolates a broader concept of discourse which he defines as "a group of statements which provide a language for talking about -ie. a way of representing-a particular kind of knowledge about a topic". ${ }^{4}$ Discourses of course involve language but they are also conditioned and produced by practices. They are a way of describing and acting towards something, be it a group of people or an idea.

11 Hall highlights the fact that cultures are not singular but plural in post-industrial societies. These cultures compete with each other for greater power or influence. However, the hegemony of any given culture does not result from coercion but requires a degree of consent from the subordinate class. One method of achieving consent is through cultural accommodation whereby hegemonic culture integrates bits and pieces of other cultures without allowing them to dramatically impact central ideas and beliefs.

\section{Mass Observation: setting an interdisciplinary precedent in British sociology}

One could cite as a significant predecessor to the Centre Contemporary Cultural Studies the pioneering work undertaken by the Mass Observation team led by Harrisson, Madge and Jennings some decades earlier. From the late 1930s through to the 1950s and 1960s this sociological project set out to record the everyday life conversations and behaviour of citizens in Britain. Members of the general public were also invited to record and send in day by day accounts of their lives in diary form. The material which came in was extremely diverse and the conclusions it led to inevitably crossed many boundaries: from personal anecdotes and commentary on private life and neighbours to reactions to major political events, this was sociology but integrated with other fields. Mass Observation's 
remit by its very nature challenged the idea of a scientific sociological method because it placed such emphasis on subjective response. For this Mass Observation was criticised and, although the documentation it has left is of considerable value to analysis of different cross-sections of British society, ultimately this criticism contributed to the demise of the research group, a larger proportion of its respondents ultimately proving to be middle class and hence lacking genuine representativeness as far as British society as a whole was concerned.

\section{Brief comparatist interlude: the interdisciplinarity of Michel de Certeau}

13 In the French context, the work of Michel De Certeau, following on in certain respects from that of Henri Lefebvre, is known for offering illuminating perspectives on questions pertaining to disciplinarity and interdisciplinarity. De Certeau's work has in common with that of the Centre for Contemporary Cultural Studies researchers an interest in everyday cultural practices and rituals, as in his L'Invention du quotidien, Vol 1 Arts de faire (1980). But he relates this to a concern with the politics of knowledge in the sense that knowledge is compartmentalized by academic disciplines. Academic disciplines, he argues in the same work, are defined as much by what they exclude as what they include. ${ }^{5}$ De Certeau's notion of 'tactics' comprises different forms of micropolitics of resistance conducted by those in society with limited power and, he argues, need to be studied in an interdisciplinary way. This is partly because they have been excluded from study by the mainstream disciplines. In this De Certeau is the descendent of sociologist Henri Lefebvre who, in his Critique de la vie quotidienne (1947), had similarly been critical of the established disciplines' unwillingness to include cultural practices of this sort within their scope.

Part of the promise of De Certeau's work lies in its call for a true interdisciplinarity fashioned out of an integrated approach to culture. What is implied is in effect an interdiscipline that would refashion itself in its response to its objects and which is hence responsive to the particularity of those objects. The breadth of De Certeau's intellectual interests and the topics which he made the focus of his books also intrinsically confirm his commitment to interdisciplinarity. If we take as an example his work Histoire et psychanalyse entre science et fiction (1987) his project to bring together in one volume two large fields of study is ornamented by his equal interest in literariness and mysticism.

\section{Interdisciplinarity today: 'toujours déjà-là'?}

15 In reality, though, interdisciplinarity goes back much further than these relatively recent instances of it which I have cited. There is a sense in which it has always existed, even in the modern period (let alone the Renaissance and the early modern period where it was common). To focus on just two fields of research, Marxist studies and postcolonial studies are both integrally interdisciplinary in essence. The broad narrative of history , economics and culture offered by Marxism is such that, although it is sometimes only taught in depth in economics and politics departments, by rights it can just as easily be of great interest to literary and moral philosophy specialists. Trotsky's Their Morals and Ours (1938) says little of economics, its focus being the ways in which socialist ethics depart 
from traditional Christian-derived morality. And twentieth century Marxist theories of literature are diverse and numerous. Hence, rather than thinking of interdisciplinarity as a new development in humanities research it would be more accurate to conclude, first, that the separation of disciplines was often encouraged, indeed even at times created rather artificially by the institutionalisation of knowledge in our institutions of learning, in particular university and school systems. And second that interdisciplinarity was, to draw on a concept formulated by Jacques Derrida, 'always already-there'. ${ }^{6}$ It in fact marks a return to a formerly commonly employed approach to humanities research, and indeed humanities and science research taken as a whole, from which the rise of specialisms and specialisation within the academy forced a departure. This departure, notably in the second half of the twentieth century, was in part the inevitable consequence of the expansion and ever-growing complexification of given fields of enquiry. In this regard, we should remain mindful of Pierre Bourdieu's rejection of the Sartrean notion of the " intellectuel total', that is of the idea that it might be possible for any one individual to 'tout penser'; as fields of knowledge required ever-increasing levels of specialisation in order to be properly addressed it was no longer possible for any one thinker to manhandle them all, Bourdieu objected. Whilst this justification for specialisation is undoubtedly founded, the further entrenchment of disciplinary separations which it encouraged proved to be a development that paralleled, even if it was not intrinsically complicit with, the postmodernist rejection of grand narratives. Sartre proved to be the last intellectual who nourished the ambition to present an all-encompassing narrative of human historical change, intellectuals since the 1970s and 1980s limiting themselves increasingly to much more narrowly delimited areas of enquiry.

Postcolonial studies, like Marxism, cannot be limited to one disciplinary area even though specialists do sometimes make literary studies or historical approaches, just to name two areas, the centrepiece of their research. The study of the phenomenon of colonialism, like the condition of postcoloniality, is by its very nature at once historical, sociological and political, as well as involving theoretical writings and diverse artistic explorations. Moreover, like Marxism, colonialism was a transnational phenomenon. Where Marxism challenges any notion that a discipline can be coextensive with a given national culture, in the manner of English literature for example, the study of colonialism goes a step further intrinsically inviting us to challenge, relativise and at times reject European categories of thought and even the concept of the nation-state itself. As such, the Eurocentrically-based history of academic disciplines is itself put into question, as are at times European assumptions about the political organization of society. What does it mean in the context of syncretic cultures as are certain African cultures, for example, to think of the artistic disciplines as being fundamentally separate and distinct in the manner that the European tradition has bequeathed to us over numerous centuries? In this way, the study of colonialism invites both interdisciplinarity by bringing numerous areas of study together, and comparatism in its crossing of borders between contrasting national contexts.

In the twentieth century, there has been a large number of thinkers whose work involved interdisciplinary approaches. To return briefly to the example of Sartre, arguably the twentieth century's emblematic committed intellectual, fields as diverse as philosophy, ethics, political thought, literary criticism, novel and playwriting were all central to his intellectual interests and output. Indeed, his oeuvre is known for being integrally interdisciplinary in the sense that each field he worked in informed and existed in 
dialectical relation to the others. To a lesser extent, contemporaries of Sartre's such as Merleau-Ponty, Simone de Beauvoir, Albert Camus and Raymond Aron, just to name some of the best-known figures of the period in French intellectual life, also produced oeuvres that were interdisciplinary in nature.

Interdisciplinarity, then, is by no means intrinsically new. It is strongly encouraged today though and it is fair to say that the anglophone universities have been leading the charge in this respect. At times this takes place via theme-based approaches to research: trauma studies, queer studies, masculinity studies are just a few of the more recent theme-based fields which are intrinsically interdisciplinary. At other times, it is part of a broader institutional logic which emphasizes the intrinsic value of scholars from different areas working together, so a move away from the lone scholar model in the direction of teams of researchers. These logics are now becoming ingrained and indeed have been ratified and underlined by the priorities which the major funding bodies like the AHRC and others in the UK context have declared to be advantageous. When researchers' chances of success in obtaining funding are greatly increased by producing interdisciplinary research proposals, it is hardly surprising that the landscape of research orientation in the humanities shifts noticeably in that direction.

Interdisciplinarity, then, should perhaps be handled with some caution especially when it is turned into some sort of agenda for humanities research. If it is not as intrinsically new as is sometimes suggested by its advocates then it may not in reality be necessary to encourage it so proactively. Doing so may have adverse effects for research in mainstream disciplines. The drive, which is very perceptible in British universities, to prioritise novelty-simply the notion that something that is new in relation to what preceded it is preferable to more of the same-can be dangerous to the production of quality research. It can encourage superficiality rather than depth and thoroughness.

One might infer however that the move in the direction of interdisciplinarity which I am describing reflects a growing awareness that specialisatiok:n has gone too far and can become a hindrance. There are also good reasons for concluding that it is a parallel development to a growing emphasis on intermedial and multimedia methodologies in contemporary research. Research which for example makes use of film or audio documents would tend almost by definition to be interdisciplinary. As research projects of this type grow in number interdisciplinarity is becoming increasingly a new norm.

\section{Interdisciplinarity and comparatism: possible future perspectives in the field of "civilisation britannique"}

21 Interdisciplinarity is an already well established method of conducting research in the field of 'civilisation britannique' in French universities. Outside of comparative literature departments, comparatism is less well established however, as is also the case in anglophone universities. The remainder of this article will be devoted to offering tentative proposals for areas which could be explored further in interdisciplinary research in the field. I will also make the case for encouraging more by way of comparative studies in the many domains (sociology, politics, history and so on) of " civilisation' research. The comparison of different national, linguistic and cultural contexts, I will argue, invariably permits a better understanding of issues as they manifest themselves in any one given socio-cultural and socio-political context. 
It may seem self-evident that comparatism is not a necessary accompaniment to interdisciplinarity. It is clearly possible to bring together different academic disciplines in one critical discourse without comparisons with other intellectual traditions or national contexts necessarily being implied. Perhaps less obvious is the fact that interdisciplinarity is not indispensable to comparatism even though in practice it is not uncommon for the two methods to be associated with each other. Whilst a comparative analysis of French and English theatre, for example, would probably benefit from contextualisation along socio-historical and politico-sociological lines, it is far from being the case that comparative literature specialists systematically introduce such extraliterary elements into their analyses. Hence, interdisciplinarity and comparatism do not necessarily require the presence of the other. Yet it is my conviction that each of these two methodologies in humanities research nevertheless benefits greatly from being combined with the other.

To speak of interdisciplinarity first, what sorts of disciplinary areas might it be useful to cross-fertilize more actively than to date in the field of 'civilisation britannique' ? I will offer only a suggestive answer to this question, indeed an answer only by way of a few examples. Arguably more could still be done, certainly in the ever-growing field of postcolonial studies, in using sociological research and data as a prism through which to understand broader macrosopic and even geopolitical currents and trends. For instance, researchers might usefully devote more time to enquiring into the ways in which the local experience of a diasporic community such as the south Asian community in British society is revealing of changing political currents such as the fortunes of right-wing nationalism. This relationship can be traced back over many decades. By starting with local-level sociological data and indicators relating to how south Asians are received and have integrated one can chart processes of evolution in the British political landscape more broadly. Today in fact, sadly, one could do the same using data concerning EU citizens living in Britain.

To turn at present to comparatism, I have indicated that I share in the view that the comparatist method can be a valuable adjunct to interdisciplinarity. ${ }^{7}$ This is particularly the case for specialists in foreign languages and cultures, but in my view holds for many other disciplines in the human and social sciences and therefore for many areas of scientific enquiry which sometimes find themselves in the civilisation disciplinary category. Relating fields of study in one culture to parallel fields in another nearly always throws up valuable results. Moreover, why deprive one's research of the advantages that comparison with another culture one knows comparably well can yield? To return to my example drawn from postcolonial studies, valuable research remains to be done relating the experience of immigrant communities in the UK with their counterparts in France. Aside from obvious differences of cultural heritage and sometimes religion, what do contrasts and similarities between the experiences of British Asian and French maghrébain communities reveal about our national cultures more broadly? Through the prism of such a comparison a wide array of themes can be studied: secularism, multiculturalism, policies of integration, and the attitudes and policies of mainstream and extremist political parties with respect to both race and cultural difference. The light which is thrown on each of these themes is different when they are viewed in relation to the parallel situation in the other country. 


\section{Comparatist side-step: the thought of Edouard Glissant as a theoretical basis for $21^{\text {st }}$ century Comparative Studies}

There are good reasons for believing that the spread of a more thorough-going, integral sort of comparatism is one of a number of much-needed methodological revolutions in humanities research that are waiting to come to fruition in the coming years. There are commentators and critical works which have argued convincingly for comparatism specifically, ${ }^{8}$ but the case is more effectively made in my estimation when it is substantiated with a deeper and more wide-ranging theoretical vision. The oeuvre of Edouard Glissant (1928-2011), the francophone world's leading postcolonial thinker of the last few decades, in my view offers such a vision. Why, one might aver, might it be valuable to introduce the thought of a francophone philosopher and writer into a discussion about comparatism and interdisciplinarity in the field of civilisation britannique ? I would contend, in true comparatist spirit, that it can be intrinsically valuable to introduce the thought of a philosopher principally associated with one linguistic and cultural context into a discussion of discipline that is concerned with another context. Secondly, it is also my contention that no convincing discussion of comparatism can be conducted by drawing exclusively or principally on monocultural and monoglot sources. Our principal focus being the value of comparatism to British studies, it makes little sense to draw mainly on anglophone, let alone British anglophone, sources. Moreover, Glissant's Caribbean postcolonial moorings gave him an intimate awareness of the complexities of cultural miscegenation and dual cultural belonging. His oeuvre is suffused with a sensitivity to cultural difference as well as to the needs of specific linguistic and cultural groups in relation to larger, more hegemonic forces. Finally, Glissant made a powerful defense of minoritarian languages which, he argued, should always resist dilution or subsumption in majoritarian cultures. This insistence is of a piece with comparatist methodology in a number of ways as I shall argue.

Central to Glissant's later thought, as articulated in works from his Poétique de la relation onwards, is the concept of opacité. To be opaque, Glissant argues, is not to be obscure or impenetrable. Rather, opacity stands in opposition to the notion of transparency which Glissant associates with the logic of French colonial domination: it was the colonialist who demanded that the cultures of given local populations be transparent, meaning that they should be more easily assimilable to the paradigm that was the French mindset. Each individual language-speaking group, Glissant insists, has a right to assert its specificity or difference in relation to others and in particular in relation to hegemonic cultures. In order to do that, it must retain its right to be incomprehensible to the linguistic and cultural other. No compromises need to be made at this level as to do so amounts to a betrayal of one's own culture and a caving in to pressure exerted by forces of domination.

What is the significance of such claims for a defence of comparatism? One of the consequences of Glissant's argument is that languages and their associated cultures are conceived of as being fundamentally distinct from one another; they co-exist in relations of contiguity as no synthesis, or fusion, takes place. A synthesis would in practice mean one language and culture being subsumed in another and that would amount to a reaffirmation of a colonial or postcolonial hierarchy of values. This aspect of Glissant's thought may seem paradoxical as Glissant is also associated with the concept of

Revue Française de Civilisation Britannique, XXIV-1 | 2019 
creolisation, a process whereby the bringing together of diverse phenomena brings about a new outcome. In reality, this paradox is more apparent than real however as, according to Glissant, when diverse phenomena enter into a process of creolisation they remain individually distinct and the situation which results from their encounter is unpredictable.

The fact that languages and cultures remain distinct in this way means that the practice of translation, Glissant argues, will remain essential in the twenty-first century and must be strongly encouraged. The protecting and preserving of individual languages and cultures implies relations of contiguity rather than assimilation or synthesis, and the only logical conclusion to be drawn from the adoption of such an approach is the full acceptance, indeed celebration, of multilingualism on the one hand and the promotion of the practice of translation on the other. Glissant embraces both multilingualism and translation, which he argues will be central to the future of intercultural communication in the twentieth-first century. Multilingualism is both a fact and a value for Glissant and indeed he goes further than this. Glissant argues that the interconnections between languages are so fundamental to their very nature that in reality, contrary to appearances in monoglot cultures, there cannot in reality be any such thing as a nonmultilingual environment. Even a person who only speaks and writes in one given language, Glissant argues, exists in a multilingual framework. "J'écris", he notes, "en présence de toutes les langues du monde."

\section{Conclusion}

Glissant's belief in the irreducibility and hence necessary contiguity of languages and cultural contexts means that his theoretical world-view lends itself particularly well to a comparatist methodology in research. What cannot be assimilated into a structure or phenomenon larger than itself must be compared with that and other entities in order best to be understood. Otherwise put, Glissant's thought contains a subterranean theory of, and injunction to make, intercultural comparisons. It is worth noting that Glissant himself hailed from a place-the francophone postcolonial Caribbean-which has long been a quintessentially relational cultural entity. Like all colonies, an island such as Glissant's home island of Martinique existed for many years in relation to the culture, language and politics of its colonial master, mainland France. Even today, the island's neocolonial status as a department of France which is entirely tied up with, but also in many respects economically subservient to, mainland France means that it exists in dialectical relation to a very present ailleurs. Moreover, Martinique exists in a region, the Caribbean, where it is surrounded by other formerly colonised islands, some of which are francophone, but others anglophone or hispanophone. Each island hence also exists in relation to the others at many levels: cultural but also economic and political. Martinique is also on the way to the Americas and hence is at a crossroads culturally between Europe, Africa and the Americas. It would hence be no exaggeration to claim that relationality and its adjunct, cultural comparison, are hardwired into the Caribbean psyche. Glissant's theories of creolisation, Relation, and multilingualism are well-known for being expressive of a Caribbean reality in the first instance, one which he then extrapolates out from to talk about intercultural communication on an international and global level. mutual understanding through ever more complex and sophisticated relations and 
interactions. It contains an injunction to facilitate intercultural dialogues and a clear if in some ways obliquely expressed encouragement to engage in comparative studies in the sphere of humanities research if not an exhortation to make comparative studies more the norm than the exception as the twenty-first century advances. As such, it sets an example and shows the way for a paradigm in the human and social sciences that remains underexplored and which is a valuable adjunct to interdisciplinarity.

Sam Coombes est Maître de Conférences à l'Université d'Edimbourg. Ses recherches portent sur le postcolonial comparé (anglophone/francophone) en rapport avec les enjeux de la mondialisation, les minorités en Grande Bretagne, et la pensée politique. Il est l'auteur de The Early Sartre and Marxism (Lang, 2008), et A Poetics of Resistance Another Globalized World Is Possible (Bloomsbury Publishing, 2018). Il est membre co-fondateur du réseau de recherche international Diaspolinks (http:// www.ed.ac.uk/literatures-languages-cultures/diaspolinks).

\section{BIBLIOGRAPHY}

ALDRICH, John, Interdisciplinarity (Oxford: Oxford Scholarship Online, 2014)

DAMROSCH, David, Global Comparatism and the Question of Language (PMLA, 2013)

DE CERTEAU, Michel, L'Invention du quotidien, Vol. 1 Arts de faire (Folio, 1990 [1980])

DERRIDA, Jacques, Marges-de la philosophie (Les Editions de minuit, 1972)

GLISSANT, Edouard, Poétique de la Relation (Gallimard, 1990)

L'Imaginaire des langues (Gallimard, 2010)

HALL, Stuart, 'Cultural Studies: Two Paradigms', in Media, Culture and Society 12 (1980), pp.23-42

'Who Dares, Fails', in Soundings, 1996, no.23

HUBBLE, Nick, Mass Observation and Everyday Life: Culture, History, Theory (Basingstoke: Palgrave, 2006)

LATOUR, Vincent, 'L'approche comparatiste en civilisation britannique', paper presented at the SAES annual conference, Reims, June 2017

LEFEBVRE, Henri, Critique de la vie quotidienne (Paris : L'Arche, 1981 [1947])

MORAN, Joe, Interdisciplinarity (London: Routledge, 2010 [2002])

SQUIRES, Geoffrey, Interdisciplinarity (London: The Group, 1975)

TROTSKY, Leon, Their Morals and Ours (London: New Park Publications, 1968 [1938])

WING, Sandra Koa Mass-Observation: Britain and the Second World War (London: Folio Society, 2007) 


\section{NOTES}

1. John Aldrich Interdisciplinarity (Oxford: Oxford Scholarship Online, 2014), p.2.

2. Joe Moran Interdisciplinarity (London: Routledge, 2010 [2002]), p.24.

3. Stuart Hall, 'Cultural Studies: Two Paradigms', in Media, Culture and Society 12, 1980, p.59

4. Stuart Hall, 'Who Dares, Fails', in Soundings 23 (1996), p.201.

5. Michel de Certeau, L'Invention du quotidien, Vol. 1 Arts de faire (Folio, 1990 [1980]), p.78.

6. Jacques Derrida, Marges - de la philosophie (Les Editions de minuit, 1972), p.43.

7. Vincent Latour argued this point convincingly in a paper entitled, "L'approche comparatiste en civilisation britannique", presented at the SAES annual conference, Reims, June 2017.

8. See for example David Damrosch Global Comparatism and the Question of Language (PMLA, 2013).

9. "I write in the presence of all the languages of the world", Edouard Glissant, L'Imaginaire des langues (Gallimard, 2010), p.34.

\section{ABSTRACTS}

Unlike in France where a separation between established disciplines is often favoured, in the United Kingdom a more interdisciplinary approach has been more widely employed (Mass Observation after the Second World War, cultural studies, to cite only two examples). For a number of years now, research financing bodies have been actively encouraging transdisciplinary projects. This article seeks firstly to offer a comparative analysis of interdisciplinary approaches in Great Britain and France in order better to pinpoint the undeniable advantages of interdisciplinarity whilst nevertheless highlighting some of its more problematic aspects. I will then approach the question of interdisciplinarity in the field of British civilisation studies via discussion of concrete examples.

In reality, interdisciplinarity has always existed and the fact that British universities often present it as an objective to be realised suggest that it has been badly understood. Being a specialist of for example John Ruskin or Charles Baudelaire necessarily implied an interdisciplinary approach as each author was both a literary writer and an art critic. Nowadays interdisciplinarity and multimedia approaches are often confused with each other because of the growing importance accorded in our society to the visual image. Interdisciplinarity has become intertwined to some extent also with the commercialisation of higher education. As our educational institutions are ranked in part according to the sums of money that they succeed in attracting for their research projects, interdisciplinarity has become a stake in a logic of survival of our institutions in so far as it is favoured in relation to specialisation.

If interdisciplinarity is hence not intrinsically new, why and how can it be employed to useful effect in the human sciences, and more specifically to enrich the field of British civilisation studies? In this article we will examine this question from a number of angles with reference to my areas of specialism, and in particular the study of minoritarian and diasporic communities in a comparative perspective.

Contrairement à la France où l'étanchéité des disciplines est plus souvent de mise que la porosité, le Royaume-Uni a depuis longtemps privilégié une approche comparativement plus 
interdisciplinaire (Mass Observation après la seconde guerre mondiale, les cultural studies, pour ne citer que deux exemples). Depuis quelques années, les organismes de financement de la recherche encouragent eux aussi les développements de projets transdisciplinaires. Dans cette communication, je proposerai dans un premier temps une analyse comparatiste des approches interdisciplinaires en Grande Bretagne et en France afin de mieux cerner les avantages incontestables de l'interdisciplinarité, mais aussi de de m'interroger sur certaines de ses limites dans le contexte du système universitaire britannique. Ensuite, j'aborderai la question de l'interdisciplinarité dans le domaine de la civilisation britannique par le biais d'exemples concrets afin de mieux mesurer les enjeux.

En réalité l'interdisciplinarité a toujours existé, et le fait que les universités britanniques la présentent si souvent comme un objectif à atteindre suggère qu'elle est mal comprise. Etre spécialiste de John Ruskin ou de Charles Baudelaire, par exemple, impliquait forcément une approche critique interdisciplinaire car ils étaient tous les deux à la fois critiques d'art et auteurs d'ouvrages littéraires. Dans la période actuelle, on confond notamment interdisciplinarité et approches multimédias à cause de l'importance toujours grandissante de l'image. L'interdisciplinarité se trouve impliquée aussi dans ce qu'il convient d'appeler 'la commercialisation de l'éducation supérieure'. Puisque nos institutions sont classées en partie en fonction des sommes d'argent que leurs chercheurs réussissent à attirer pour leurs projets de recherche, l'interdisciplinarité devient un enjeu dans une logique de survie de nos institutions dans la mesure où elle est privilégiée par rapport à la spécialisation.

Si l'interdisciplinarité n'est pas une nouveauté, pourquoi et comment peut-on l'employer pour le bien des disciplines des sciences humaines, et plus spécifiquement pour enrichir le domaine de la civilisation britannique? Dans cette communication je poursuivrai quelques pistes en me référant à mes propres spécialités, et notamment l'étude des communautés minoritaires et diasporiques dans une perspective comparatiste.

\section{INDEX}

Mots-clés: interdisciplinarité, comparatisme, cultural studies, nouveaux discours critiques, Edouard Glissant

Keywords: interdisciplinarity, comparatism, cultural studies, new critical discourses, Edouard Glissant

\section{AUTHOR}

\section{SAM COOMBES}

Associated Member of CREW-CREC (Université Sorbonne Nouvelle-Paris 3), University of Edinburgh 